\title{
Ecohealth is coming to (London) town-and a Blackbird sings in Russell Square!
}

This year, we are holding our international biennial conference in London, capital city of the United Kingdom, one of the largest urban centers in Europe and an ancient urban ecosystem. This meeting is the third since the International Association for Ecology and Health (IAEH) formed in 2003 and is our first conference since our transition from a charter board. Congratulations all those who are supporting the Ecohealth 2010 conference in London-you will be attending the first fully fledged meeting of our now coming-of-age scientific association.

As Chair of the Ecohealth 2010 conference and a member of the Board of the IAEH, I have watched the association grow into a dynamic scientific community of researchers and students, all passionate about the world's ecosystem and its diverse inhabitants. We now have a flourishing journal that publishes papers from across the disciplines we represent. Both the journal and the IAEH advocate a visionary, transdisciplinary science to support our understanding of and action on some of the earth's most pressing challenges.

When I first offered to hold the IAEH conference at the London School of Hygiene and Tropical Medicine (LSHTM), I was based in London, cycling every day from my home and wildlife garden into the center where the LSHTM is based, through several of our 14 urban ecosystems and via four of our beloved parks and garden squares. We have more than 2,000 ha of parks and public gardens in central London, not counting all of the gardens of Londoners, nor the bigger parks and open spaces that surround the city and suburbs.

I now live in a 12,000-ha biological reserve in the Yungas (mountain cloud forest) of Northern Argentina, and I travel to the High Andes and Amazonia for my work with indigenous communities. Chairing the conference from here has meant regular teleconferences on Skypeoften from Internet cafes and sometimes, connection permitting, from an open space between the trees in the reserve.

It is strange to work and have homes in such different parts of the world's ecosystems: urban metropolis and remote forest. Both settings are major themes not only for the conference, but also for the world's policymakers. This year, biodiversity is a major topic for the United Nations, as monitoring systems globally report on the world's biodiversity and our dismal record on protecting our most precious biodiverse regions. Meanwhile, urbanization presents a major challenge to policymakers at all levels, with more than $50 \%$ of the world's population now living in towns and cities, many in deep poverty and environmental deprivation.

It is a privilege to be Chair of a conference in London that brings these topics together, and to have been working on the conference from one of the most biodiverse regions of the world. To set the scene for our conference, let's look briefly at how these different ecosystems and their inhabitants are faring in 2010.

Latin America is home to some of the Earth's most important ecosystems. As the Amazonian forest reaches the Andes, it merges with a contiguous biosphere: the Yungas. These two sister forest ecosystems are among the most biodiverse regions of the world, spanning several Latin American countries, including Brazil, Argentina, Peru, and Bolivia. In these four countries alone, these ecosystems span more than six million square kilometers, roughly 25 times the size of the United Kingdom.

For millennia, spanning modern geopolitical boundaries, Amazonia and the Yungas have been protected by 
more than 400 different indigenous peoples. In Brazil, where some of the most critically threatened Amazonian frontier zones are located, recent research shows that indigenous territories have proved to be the most effective type of conservation unit, with deforestation rates 2.5 times lower than federal conservation areas, such as national parks. In turn, Amazonia and the Yungas have provided these indigenous peoples with food, home, culture, medicines, and natural resources. These forest biospheres also provide the world with some of its most important ecosystem services in terms of forest and food resources, current and potential new medicines, rainfall regulation, and a global carbon sink.

Internationally, there is an urgent need to improve understanding of the importance of biodiversity for human health and well-being, particularly for communities directly dependent on biodiverse ecosystems. The need is especially urgent in this fragile and vital region, home to such interdependent biological and cultural diversity. Emerging studies by biologists and ecologists have documented the extent of the threat to the Yungas and Amazonia-and their ecosystem services-from exogenous forces, such as deforestation, resource extraction, and climate change.

There is parallel evidence from social and health scientists that indigenous communities, who are among the most marginalized peoples internationally and are the poorest population group in South America, are experiencing increasing threats to their health and well-being. Destruction of these ecosystems and their wise indigenous guardians has potential impacts globally. We could lose vital ecosystems that provide current and future food and medicines, and we lose the important knowledge of the indigenous guardians of Amazonia and the Yungas. A deteriorating health situation weakens the ability of indigenous communities to protect these vital ecosystems. The loss of their indigenous guardians not only increases the physical vulnerability of the forests of Amazonia and the Yungas, but also deprives the world of the indigenous knowledge and management skills that are key to ensuring the continued provision of their ecosystem services.

On the other side of the planet sits London, the home of this year's conference. London has been a renowned city for centuries-both for its beauty and for its problems. London was home to the Great Plague in 1665, and then to the Great Fire, which destroyed much of London in 1666. Known for decades in the $20^{\text {th }}$ century as "the Big Smoke" for the coal-fire air pollution that hung over the city, London's air is now much cleaner, and a daily monitoring system helps guide policymakers and citizens. We still have a long way to go compared with many European cities, but the "green lungs" of London make a major contribution to our air quality.

Perhaps now more than ever, London is a truly international city. Londoners come from all parts the world to make this unique city their home. One-third of Londoners-approximately 2.3 million people-were born outside of the United Kingdom and come from all parts of the world. Londoners speak more than 300 languages, and in London you can find all the languages, faiths, cultures, (and foods!), of the world.

London also has a thriving ecological life, with one of the cleanest rivers in Europe. Overall, the United Kingdom has 40 terrestrial/freshwater habitats, and 25 marine habitats. Nationally, 1,200 marine, terrestrial, and freshwater species are on the UK Priority List of Species. London also has a diversity of wildlife and ecosystems and has 14 river, canal, woodland, and urban habitats. This includes some expected and unexpected urban habitats; as you might imagine, the tidal Thames is a major habitat, as are built structures and wasteland. But London also has woodland, heath land, reed beds, rivers, and streams. Cemeteries and graveyards are very important for birds and small mammals, as are acid grasslands, canals, private gardens, and (of course) our parks and urban green spaces.

The London Biodiversity Partnership and the London Wildlife Trust both hold a wealth of information on London's ecosystems. They report at least eight species of bat living with us in the city. You can see one of the rarest of European birds-the peregrine falcon-nesting on the rooftops of our art galleries and tower blocks; and if you stay out late at night, you can hear and often see one of London's 10,000 resident foxes! Alongside the existing species we are reintroducing some of London's old residents, such as the water vole, which once thrived along London's rivers and streams.

Returning to the conference, I am delighted that we will have such an interesting three days, discussing some of the major challenges facing us as scientists and citizens. The LSHTM is in the heart of London in the academic Bloomsbury area of town, famous for its radical literary and political inhabitants. I am sure you will find the area interesting and hope you will also find time to relax in the patchwork of garden squares that dot the area. 


\section{Carolyn Stephens}

International Indigenous and Environmental Health, London School of Hygiene and Tropical Medicine, London, UK

e-mail: carolyn.stephens@lshtm.ac.uk

\section{Carolyn Stephens}

International Indigenous and Environmental Health, National University of Tucumán, Tucuman, Argentina

\section{BIBLIOGRAPHY}

Bristow F, Stephens C, Nettleton C, W'achil U (editors) (2003) Utz' Wach'il: Health and Well-being Among Indigenous Peoples, London: Health Unlimited and the London School of Hygiene and Tropical Medicine

Brown A, et al. (2007) Finca San Andres-Un espacio de cambios ambientales y sociales en el Alto Bermejo, Yerba Buena: Ediciones del Subtropico

Fundacion Proyungas (2007) Bitácora de las Yungas: Bosques Nublados, Tucuman: Fundacion de las Yungas

Hall G, Patrinos HA (2005) Indigenous Peoples, Poverty and Human Development in Latin America: 1994-2004, Washington: The World Bank
Kappelle MIn: Brown A (editors) (2001) Bosques Nublados del Neotrópico, San Jose, Costa Rica: Editorial INBio

Kunst CR, Bravo S, Panagatti JL (editors) (2003) Fuego en los ecosistemas argentinos. Santiago del Estero: Instituto Nacional de Tecnología Agropecuaria

Miranda CP (2003) Tucumán y Los Recursos Naturales. Biodiversidad Los Recursos Silvestres, Los Ambientes Naturales y Las Areas Protegidas, Tucumán: Gobierno de La Provincia de Tucumán

Montenegro RA, Stephens C (2006) Indigenous health in Latin America and the Caribbean. Lancet 367(9525):1859-1869

Redford KH, Naughton L, Ráez-Luna EF (2000) Forest wildlife and its exploitation by humans. In: The Conservation Atlas of Tropical Forests: The Americas, Harcourt CS, Sayer JA (editors), New York: Simon and Schuster/IUCN International Union for Conservation of Nature

UNEP WCMC, Tyrrell T (editors) (2008) Indicators on the Health of Well-being of Communities Directly Dependent on Local Ecosystems, Oxford: WCMC United Nations Environment Programme, World Health Organisation, 2010 Biodiversity Indicators Partnership

U.S. Government (2003) Conserving Biodiversity in the Amazon Basin: context and opportunities for USAID, Washington, DC: USAID

Published online: July 28, 2010 